\title{
Comparison of Physical-chemical and Mechanical Properties of Chlorapatite and Hydroxyapatite Plasma Sprayed Coatings
}

\author{
Imane Demnati ${ }^{1}$, David Grossin ${ }^{1}$, Olivier Marsan ${ }^{1}$, Ghislaine Bertrand ${ }^{1}$, Gérard Collonges ${ }^{2}$, \\ Christèle Combes ${ }^{1}$, Maria Parco ${ }^{3}$, Inigo Braceras ${ }^{3}$, Joel Alexis ${ }^{4}$, Yannick Balcaen ${ }^{4}$ and \\ Christian Rey ${ }^{1, *}$
}

${ }^{I}$ Université de Toulouse, CIRIMAT, INPT-CNRS-UPS, ENSIACET, Toulouse, France

${ }^{2}$ PS: Projection Plasma System, Montbazens, France

${ }^{3}$ Tecnalia, Mikeletegi Pasealekua 2, Donostia-San Sebastian, Spain

${ }^{4}$ Université de Toulouse, INPT-ENIT, Laboratoire Génie de Production, Tarbes, France

\begin{abstract}
Chlorapatite can be considered a potential biomaterial for orthopaedic applications. Its use as plasma-sprayed coating could be of interest considering its thermal properties and particularly its ability to melt without decomposition unlike hydroxyapatite. Chlorapatite (ClA) was synthesized by a high-temperature ion exchange reaction starting from commercial stoichiometric hydroxyapatites (HA). The ClA powder showed similar characteristics as the original industrial HA powder, and was obtained in the monoclinic form. The HA and ClA powders were plasma-sprayed using a low-energy plasma spraying system with identical processing parameters. The coatings were characterized by physicalchemical methods, i.e. X-ray diffraction (XRD), Fourier transform infrared spectroscopy (FTIR) and Raman spectroscopy, including distribution mapping of the main phases detected such as amorphous calcium phosphate (ACP), oxyapatite $(\mathrm{OA})$, and $\mathrm{HA}$ or $\mathrm{ClA}$. The unexpected formation of oxyapatite in $\mathrm{ClA}$ coatings was assigned to a side reaction with contaminating oxygenated species $\left(\mathrm{O}_{2}, \mathrm{H}_{2} \mathrm{O}\right)$. ClA coatings exhibited characteristics different from HA, showing a lower content of oxyapatite and amorphous phase. Although their adhesion strength was found to be lower than that of HA coatings, their application could be an interesting alternative, offering, in particular, a larger range of spraying conditions without formation of massive impurities.
\end{abstract}

Keywords: Chlorapatite, FTIR, hydroxyapatite, low energy plasma spraying, mechanical testing, Raman, XRD.

\section{INTRODUCTION}

Orthopaedic implants, especially those intended to restore the function of load-bearing joints (hip, knee, shoulder, elbow, ankle, finger...) of aged or injured human beings, should possess several attributes to meet the high level of mechanical stresses, wear, and fatigue in the course of normal activity. Although they may differ depending on the type of joints, these attributes include mechanical properties (elasticity, yield stress, ductility, toughness, and wear resistance) as well as biological properties (biocorrosion resistance, biocompatibility, good and longterm osseointegration). Metallic materials are most commonly used for load bearing implants. Stainless steel, cobalt alloys and titanium alloys are accordingly commercially available for bone substitutes, artificial joints and dental implants [1,2]. Durability and functionality of the implant are governed mainly by the properties of the bulk material, whereas the biological response depends, among

*Address correspondence to the author at the Université de Toulouse, CIRIMAT, INPT-CNRS-UPS, ENSIACET, Toulouse, France;

Tel: +33 5343234 84; Fax: +33 5343234 98;

E-mail: christian.rey@ensiacet.fr others, on the surface characteristics of the implantable device. Indeed, a crucial step for the implant stability is the formation of the effective interface between the bone and the implanted material. Several surface characteristics favour this osseointegration: mechanical interlocking related to surface roughness and physical characteristics, and direct chemical interactions involving bonds between the implant surface and bone tissue constituents. To promote the osseointegration of metallic implants, morphological (3D texturing, surface roughness and porosity) and chemical (ion implantation, grafting, and coating) modifications of the implant surface have been proposed [3, 4]. Since the mid1980 s, plasma sprayed hydroxyapatite (HA) $\left(\mathrm{Ca}_{10}\left(\mathrm{PO}_{4}\right)_{6}\right.$ $(\mathrm{OH})_{2}$ ) coatings appear as the most developed and successful treatments of metallic, especially titanium-based, implants for a fast integration to bone tissues [5-13]. Indeed, atmospheric plasma spraying (APS) is the most widely used commercial technique due to its process simplicity, low cost, and bulk production [14]. During plasma spray, the material to be deposited (feedstock), typically as powder, is introduced into the core of a plasma plume emanating from a d.c. torch. The powder is fully or partially melted, and accelerated towards the work piece, upon which it impacts 
and cools down to form a coating by overlapping of splats. Depending on the plasma-forming gases, electrical characteristics, feedstock attributes, and kinematics conditions, the thermal input transferred to the in-flight particles and coating, together with the cooling rate, can result in severe powder decomposition and in lack of crystallinity. Starting from HA feedstock it is noteworthy that plasma spray can induce the formation of amorphous calcium phosphate (ACP), tricalcium phosphate $(\alpha$ or $\beta$ $\mathrm{TCP})$, tetracalcium phosphate (TTCP), calcium oxide $(\mathrm{CaO})$ and dehydroxylated products (oxyhydroxyapatite or oxyapatite) $[5,7,15-21]$. The decomposition sequence occurs along the powder trajectory in the plasma jet that is determined mainly by the particles' size, density and their dwell-time in conjunction with many parameters, for example the viscosity and density of the plasma. The degree of crystallinity of plasma sprayed HA coatings is usually between 65 and 85 vol. \% (in some operating conditions it may reach 93 vol. \%) [7, 15, 22-26]. Crystalline HA is seen as a crucial factor for long-term coating stability in vivo. Although the presence of relatively soluble non-apatitic calcium phosphate salts such as ACP, TCP, and TTCP has been found to accelerate the bone attachment, these phases are related to long-term non-uniform coating degradations that adversely affect the prosthetic stability of the implants $[4,27-34]$. To limit the amount of easily soluble $\mathrm{CaP}$ phases, the steep temperature gradients during plasma spraying have to be reduced by increasing the substrate temperature and controlling the cooling rate and/or by limiting the thermal transfer. One method to control the degree of melting of the powder could be achieved by micro plasma spray (MPS, also called MIPS) or low-energy plasma spray (LEPS) techniques [35-42]. Due to the low heat input of these plasma torches, overheating of the powder particles as well as excessive local overheating of the coating can be avoided. LEPS also allows the production of highly porous (around 20 vol. \%)-thick coatings (about $250 \mu \mathrm{m}$ ) without accumulation of residual stresses (tensile stresses are detrimental because they promote cracks and accelerate dissolution) and without negatively affecting the mechanical properties (fracture toughness of about $0.6 \mathrm{MPa} \cdot \mathrm{m}^{1 / 2}$ ). In a previous work, we have implemented such an innovative low energy plasma spray system that has resulted in producing thin dense HA coatings with a good degree of crystallinity (around 70\%) and improved purity, compared to conventional high-energy APS coatings, as demonstrated by Raman studies [43]. Another strategy to overcome the decomposition of HA and thus limit the presence of soluble $\mathrm{CaP}$ phases is to use calcium apatites with higher thermal stability such as fluorapatite (FA) or chlorapatite (ClA) [44-48]. Indeed, it has already been demonstrated that both materials lead to coatings with superior adhesive strength to the substrate as well as without significant thermal degradation. Fluorapatite and fluorhydroxyapatite (FHA) as raw material or coatings have been extensively studied [45-47]. In vitro tests have demonstrated the ability of such material to favour the osteoblast attachment, to support the cytocompatibility, to exhibit an antibacterial effect, and to stimulate cell proliferation and differentiation. In weight-bearing model (in vivo), no statistical difference in loss of ceramic coating was found between HA and FA coatings and durable implant fixation was always concluded.
The objective of the current study is to compare chlorapatite and hydroxyapatite coatings obtained by a LEPS gun. Until today only a few authors have worked on the substitution of chloride ion in hydroxyapatite, and no commercial product is available. Hence, our first aim was to develop a simple and fast reaction synthesis transposable at an industrial scale. A method is first described to prepare easily chlorapatite from commercial HA preserving similar powders characteristics. The main physical-chemical and mechanical properties of the coatings obtained with a low energy plasma spraying process are compared using standardized procedures and specific techniques such as Raman microscopy mapping of the main mineral phases found in the coating and three points mechanical bending with stiffener.

\section{POWDERS PREPARATION AND CHARACTERISTICS}

The hydroxyapatite used in this study was a commercial product (Teknimed, L'Union, France). The XRD analyses, according to ISO standard (ISO 13779-3: 2008), did not detect any crystalline impurity (Fig. 1) and the FTIR spectrum (Fig. 2) was the same as that of stoichiometric hydroxyapatite.

Regarding the synthesis of chlorapatite, several methods have been proposed $[49,50]$. Precipitation methods in aqueous media do not lead generally to stoichiometric chlorapatite and the apatite obtained contains always hydroxide ions. Several dry synthesis methods giving stoichiometric $\mathrm{ClA}$ with a high purity have been proposed. The reaction of $\mathrm{CaCl}_{2}$ on $\mathrm{Ca}_{3}\left(\mathrm{PO}_{4}\right)_{2}\left(800-1100^{\circ} \mathrm{C}\right)$ [50] results in $\mathrm{ClA}$ with a high yield, especially when using an excess of $\mathrm{CaCl}_{2}$, which can be removed by washing. Other methods can be used, especially $\mathrm{Cl}-\mathrm{OH}$ ion exchange reactions on $\mathrm{HA}\left(800-1100^{\circ} \mathrm{C}\right)$, which offers the advantage of using an existing commercial product. Several chlorinating agents can be used for this exchange reaction, such as $\mathrm{CaCl}_{2}$ :

$\mathrm{CaCl}_{2}+\mathrm{Ca}_{10}\left(\mathrm{PO}_{4}\right)_{6}(\mathrm{OH})_{2} \rightarrow \mathrm{Ca}_{10}\left(\mathrm{PO}_{4}\right)_{6} \mathrm{Cl}_{2}+\mathrm{CaO}+\mathrm{H}_{2} \mathrm{O}(1)$

This reaction leads to the formation of $\mathrm{CaO}$, which is difficult to remove. Other chlorinating agents could be used and more interestingly, chlorinating gases, such as $\mathrm{HCl}$, which would not produce any residues except water. This reaction has been studied by Hoekstra [49] at about $1050^{\circ} \mathrm{C}$ and has been shown to lead to formation of stoichiometric ClA:

$\mathrm{Ca}_{10}\left(\mathrm{PO}_{4}\right)_{6}(\mathrm{OH})_{2}+\mathrm{HCl} \leftrightarrow \mathrm{Ca}_{10}\left(\mathrm{PO}_{4}\right)_{6} \mathrm{Cl}_{2}+\mathrm{H}_{2} \mathrm{O}$

This reaction is supposed not to alter the powder characteristics (e.g. grain size, shape). One of the difficulties in such a reaction is to handle hydrogen chloride gas, and, to overcome this difficulty, we choose as a precursor of $\mathrm{HCl}$, $\mathrm{NH}_{4} \mathrm{Cl}$ which decomposes at about $340^{\circ} \mathrm{C}$ under atmospheric pressure, into $\mathrm{NH}_{3}$ and $\mathrm{HCl}$. In such a synthesis we should keep in mind, that non-stoichiometry has been reported to occur in ClA heated at high temperature, which has been assigned to the release of $\mathrm{CaCl}_{2}$ [51]:

$\mathrm{Ca}_{10}\left(\mathrm{PO}_{4}\right)_{6} \mathrm{Cl}_{2} \rightarrow \mathrm{Ca}_{10-\mathrm{x}}\left(\mathrm{PO}_{4}\right)_{6} \mathrm{Cl}_{2-2 \mathrm{x}}+\mathrm{xCaCl}$

Previous attempts to use the reaction of $\mathrm{HA}$ with $\mathrm{NH}_{4} \mathrm{Cl}$ by A. Hoekstra [49] have probably failed to produce 
stoichiometric $\mathrm{ClA}$ because the treatment temperature $\left(1180^{\circ} \mathrm{C}\right)$ was too high. The second point to consider is the fast hydrolysis of $\mathrm{ClA}$ into $\mathrm{HA}$ when traces of water molecules are present. Thus, we shall use a temperature as low as possible, resulting in a reasonable reaction rate and enabling to preserve a dry atmosphere.

The ion exchange reaction was performed in a tubular oven under a flux of dry nitrogen enriched with sublimated $\mathrm{NH}_{4} \mathrm{Cl}$ in large excess placed in a zone of the tubular oven at about $400^{\circ} \mathrm{C}$ [52]. The unreacted $\mathrm{HCl}$ in the gas flow recombines with $\mathrm{NH}_{3}$ and regenerates $\mathrm{NH}_{4} \mathrm{Cl}$, which crystallizes at the outlet of the oven and could possibly be recycled. The reaction was fast at $950^{\circ} \mathrm{C}$ and a few grams of $\mathrm{HA}$ were transformed into $\mathrm{ClA}$ in about 15 minutes. However, for production treatments of the order of several hundreds of grams on partly sintered HA grains of industrial HA the treatment time was two hours [52].

The XRD analyses (Fig. 1) of the samples obtained indicated the formation of chlorapatite in its monoclinic form, which is the stable low temperature isomorph. The monoclinic $\mathrm{ClA}$ has been shown to correspond to an order among the $\mathrm{Cl}^{-}$ions of the chlorapatite [53]. The tiny peaks of the superstructure related to this ordering can be distinctly seen on the XRD diagram Fig. (1). The transition temperature to the hexagonal structure of $\mathrm{ClA}$ occurred as expected at about $200^{\circ} \mathrm{C}$. The unit cell dimensions (Table 5) appeared consistent with that of a stoichiometric chlorapatite.

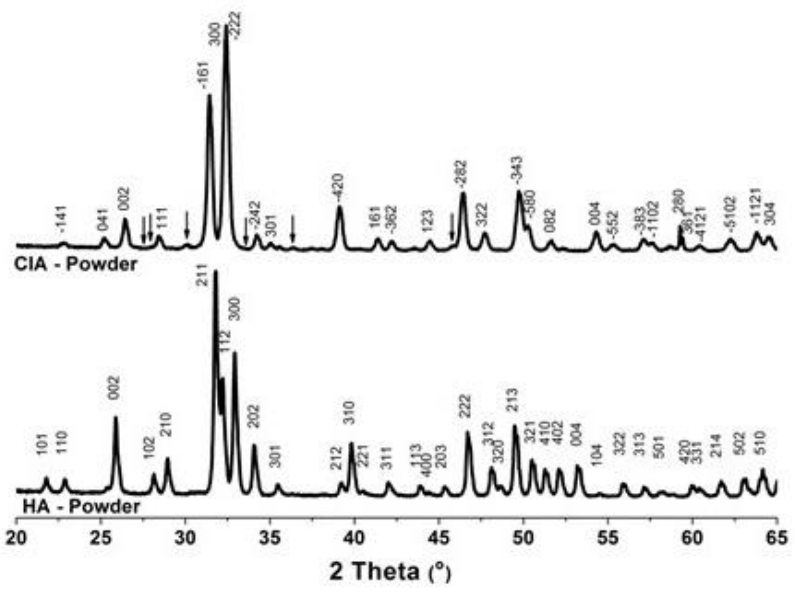

Fig. (1). Diffraction patterns of the HA and ClA powders used in this work. Superlattice lines on ClA pattern are shown by arrows.

Theoretically stoichiometric HA should also exist as a monoclinic apatite at room temperature. However, most industrial HA crystallize in the hexagonal systems. This anomaly is often attributed to the existence of defects and impurities, which stabilizes the hexagonal form of HA. On the other hand, chlorinating treatments have been shown to remove several impurities present in the apatite structure as volatile chlorides and this reaction has been proposed for the extraction of transition elements, rare earths and uranides from apatitic ores [54]. Although we did not determine the effect of the chlorination treatment on the level of impurities, this possibility could be an interesting additional advantage of the chlorination treatment.

FTIR data (Fig. 2) confirm the removal of the $\mathrm{OH}^{-}$ions, the stretching $\left(3570 \mathrm{~cm}^{-1}\right)$ and librational $\left(633 \mathrm{~cm}^{-1}\right)$ lines of which cannot be seen on the spectra after chlorination. The lines characteristic of $\mathrm{OH}-\mathrm{Cl}$ interactions in solid-solutions of $\mathrm{HA}$ and $\mathrm{ClA}$, at $3495,3510 \mathrm{~cm}^{-1}$ [55] cannot be observed either, suggesting a complete replacement of $\mathrm{OH}^{-}$ions by $\mathrm{Cl}^{-}$ ions in the apatite structure.

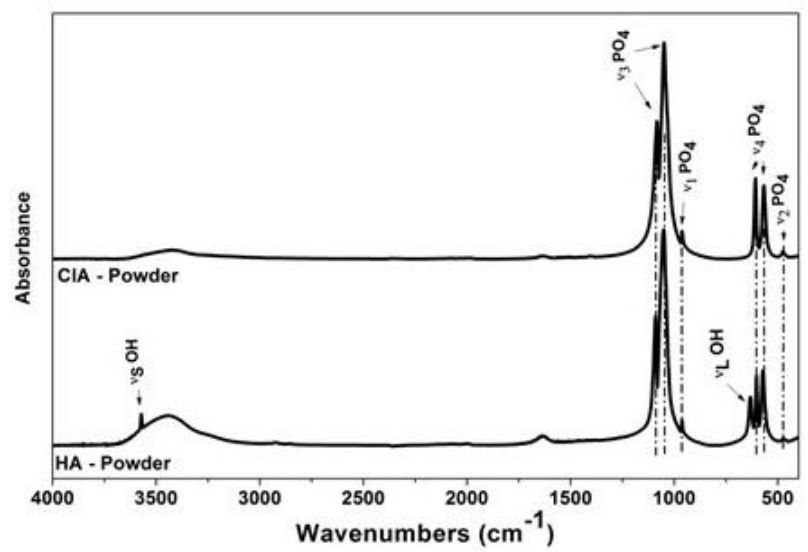

Fig. (2). FTIR spectra of the HA and ClA powders used in this work. Apatitic phosphate absorption bands are indicated by dotted lines.

The morphology of the HA and ClA powders are shown in Fig. (3). Their main characteristics $(\mathrm{Ca} / \mathrm{P}$, particle size, specific surface area, flowability) are reported in Table $\mathbf{1 .}$

The grains in both samples show irregular shapes related to the preparation of HA granules by grinding of sintered particles and subsequent sieving. The surface irregularities can be seen on ClA grains, which were not apparent on HA ones. Granulometry (Malvern Matersizer 2000) revealed a similar grain distribution for both $\mathrm{HA}$ and $\mathrm{ClA}$ powders. The grain sizes extended from 0.7 to $140 \mu \mathrm{m}$ with a main distribution peak between 50 and $80 \mu \mathrm{m}$ and smaller ones between $0.7-3 \mu \mathrm{m}$ and 3-20 $\mu \mathrm{m}$ [52]. On chlorination, the median grain size $\mathrm{d}_{0.5}$ has decreased, presumably due to fragmentation of the initial HA grain during the chlorination process. The flowability was determined, according to the recommendations of the European Pharmacopoeia, by measuring the flow time of $100 \mathrm{~g}$ of powder through a funnel with specified dimensions [52]. The flowability of the

Table 1. Main characteristics of the powders

\begin{tabular}{|c|c|c|c|c|}
\hline Powders & Ca/P & Specific surface area $\left(\mathbf{m}^{\mathbf{2}} \mathbf{g}^{-\mathbf{1}}\right)$ & Granulometry $\mathbf{d}_{\mathbf{0 . 5}}(\boldsymbol{\mu m})$ & Flowability $(\mathbf{s})$ \\
\hline \hline HA & $1.66 \pm 0.02$ & $1.44 \pm 0.07$ & 69.5 & $27.26 \pm 3.44$ \\
\hline ClA & $1.67 \pm 0.02$ & $1.48 \pm 0.15$ & 56.5 & $4.75 \pm 0.32$ \\
\hline
\end{tabular}



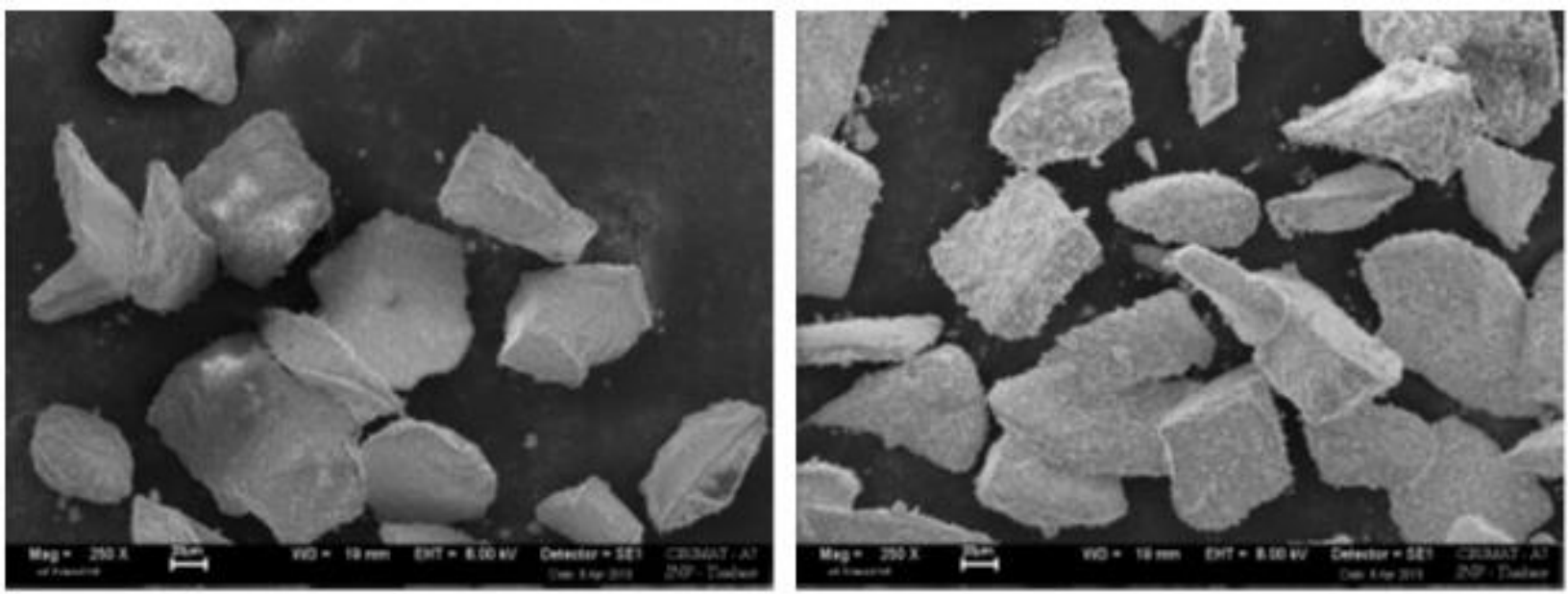

Fig. (3). SEM images of HA (left) and ClA (right) powders.

powders appeared significantly different and this observation might be possibly related to a change in surface characteristics as observed by SEM, although this remains difficult to elucidate.

In addition, Rietveld analyses of XRD data reveal that the chlorination treatment induced, unexpectedly, a decrease in the average size of the $\mathrm{ClA}$ crystals compared to the industrial HA crystals in the starting powder (Tables $\mathbf{4}$ and 5).

Comparison of the phase diagrams, $\mathrm{CaO}-\mathrm{P}_{2} \mathrm{O}_{5}$ for $\mathrm{HA}$ and $\mathrm{CaCl}_{2}-\mathrm{Ca}_{3}\left(\mathrm{PO}_{4}\right)_{2}$ for $\mathrm{ClA}[50,56]$ indicate a decomposition of $\mathrm{HA}$ on heating, whereby $\mathrm{ClA}$ melts without decomposition. This property is a major argument in favour of the use of $\mathrm{ClA}$ for producing plasma sprayed coatings: the formation of foreign phases is expected to be limited, except for the amorphous phase resulting of the quenching of a melted phase.

The comparison of the solubility of $\mathrm{HA}$ and $\mathrm{ClA}$, which could determine possible differences in bioresorption of the coatings, is also interesting. However, published data on ClA solubility are scarce and provide incoherent values. Thus $\mathrm{ClA}$ has been reported to be less soluble than HA [57], although thermodynamic data strongly suggest that it should be more soluble than $\mathrm{HA}$ with a solubility product $\mathrm{pK}_{\mathrm{sp}}(\mathrm{ClA})$ $=108$ at $25^{\circ} \mathrm{C}\left(\mathrm{pK}_{\mathrm{sp}}(\mathrm{HA})=116.8\right.$ for $\left.\mathrm{Ca}_{10}\left(\mathrm{PO}_{4}\right)_{6}(\mathrm{OH})_{2}\right)$ [58]. However, considering the concentration of $\mathrm{Cl}^{-}$ions in body fluids of more than $10^{5}$ times higher than that of $\mathrm{OH}^{-}$in serum at physiological $\mathrm{pH}$, the effect of this difference would be minor. It should be noticed that the incorporation of chloride ions in biological apatites, especially enamel, has been confirmed [59].

\section{COATINGS DEPOSITION}

\section{Thermal Spraying}

The powders (HA and $\mathrm{ClA}$ ) were sprayed in air on surgical grade (grade 4) Ti disks (12 $\mathrm{mm}$ in diameter and 3 $\mathrm{mm}$ in thickness), using a low energy plasma spray (LEPS) device [43]. This system was an experimental low energy plasma spray system designed and developed by InasmetTecnalia (Spain) from commercial Sulzer Metco torch
(Switzerland). Ti substrates were previously degreased and then sandblasted with corundum F150 using a pressure of 2 bars to produce a surface roughness (Ra) of about $1 \mu \mathrm{m}$. Coupons were separately sprayed with chlorapatite or hydroxyapatite under the same thermal spraying conditions (Table 2). For practical reasons, the gun operated with standard electrodes. The entire gun was cooled with water and a glass fibre-reinforced epoxy housing separated the electrical poles. A more detailed description of the LEPS system has been provided elsewhere [60]. Coatings with various thicknesses were obtained simply by changing the number of torch runs $(1,6,12$ and 20 runs) for both HA and ClA powders. We can see on Table 3 that the coating thickness depended not only on the number of runs, but also on the nature of the apatite: whatever the number of spray runs, the HA-coatings were always thicker than the ClAcoatings. This observation can be related to the decrease of the median grain size associated with the chlorination treatment, and possibly to a certain additional fragility of the grains, although other causes could be envisioned such as the viscosity of the melted phase for example, which is supposed to be totally liquid in the case of ClA whereas it may contain solid $\mathrm{CaO}$ in the case of $\mathrm{HA}$.

Table 2. Torch characteristics and plasma spray conditions

\begin{tabular}{|l|r|}
\hline \multicolumn{1}{|c|}{ Torch Type } & Sulzer Metco; Switzerland \\
\hline \hline Powder level $(\mathrm{kW})$ & $15 \mathrm{~kW}$ \\
\hline Current (A) & 400 \\
\hline Gas & Argon \\
\hline Spraying velocity $\left(\mathrm{mm} \cdot \mathrm{s}^{-1}\right)$ & 200 \\
\hline Plasma gas rate $\left(\mathrm{Ar} ; \mathrm{L} \cdot \mathrm{mn}^{-1}\right)$ & 24 \\
\hline Stand-off distance $(\mathrm{mm})$ & 40 \\
\hline Carrier gas rate $\left(\right.$ Ar; $\left.\mathrm{L} \cdot \mathrm{mn}^{-1}\right)$ & 4 \\
\hline Powder particle size $(\mu \mathrm{m})$ & $50-80$ \\
\hline Powder feeding rate $\left(\mathrm{g} \cdot \mathrm{mn}^{-1}\right)$ & 8 \\
\hline Number of spray runs & $1 ; 6 ; 12 ; 20$ \\
\hline
\end{tabular}


Table 3. Coating thickness as a function of the number of runs and of the type of apatite.

\begin{tabular}{|c|c|c|c|c|}
\hline & \multicolumn{2}{|c|}{ Coating thickness $(\boldsymbol{\mu m})$} & \multicolumn{2}{c|}{ Thickness per run $\left(\mu \mathrm{m}\right.$. run $\left.^{-1}\right)$} \\
\hline Number of runs & HA-coating & ClA-coating & HA-coating & ClA-coating \\
\hline \hline 1 & $28 \pm 4$ & $16 \pm 4$ & $14.2 \pm 0.7$ & $10.0 \pm 0.7$ \\
\hline 6 & $85 \pm 4$ & $60 \pm 4$ & $13.4 \pm 0.3$ & $10.0 \pm 0.3$ \\
\hline 12 & $161 \pm 4$ & $120 \pm 4$ & $13.7 \pm 0.2$ & $9.0 \pm 0.2$ \\
\hline
\end{tabular}

\section{PHYSICAL-CHEMICAL CHARACTERISTICS OF THE COATINGS}

\section{Structural and Chemical Composition of the Coatings}

Surface and bulk composition of HA and ClA coatings were determined. The coating surface was analysed directly on the as-sprayed coatings. For the bulk characterizations, the coatings were scrapped and ground as indicated in the ISO standard (13779-3: 2008). Investigations on coating microstructure were also performed on sample cross-sections prepared as follows: the coupons were cut with a diamond disc (Struers) and then the half-coupon was embedded into an epoxy resin under vacuum. The embedded cross-sections were polished using a silicon carbide paper (1000 and 1200 grade $\mathrm{SiC}$ paper). Further polishing was conducted using 2400 then 4000 grade $\mathrm{SiC}$ paper to obtain a flat surface suitable for analysis.

\section{$X$-ray Diffraction Analysis of the Coatings}

Standards have been published concerning the coating's chemical composition $(\mathrm{Ca} / \mathrm{P}$ ratio), phase composition, and crystallinity (ISO 13779-2 and 3:2008). These standards are based essentially on X-ray diffraction (XRD) analyses.

$\mathrm{X}$-ray diffraction studies on both powders and coatings were carried out in order to identify the composition of the coating (obtained after 12 spray runs) and determine its crystallinity, according to the ISO 13779-3: 2008 standard. A Seifert XRD-3000 diffractometer (Germany) with a $\mathrm{CuK}_{\alpha}$ radiation over a $2 \theta$ range of $20-65^{\circ}$ was used. Patterns were collected at a step increment of $0.02^{\circ}$, with a collection time of 24 seconds at each step. According to the standard, the HA-coatings crystallinity $(\mathrm{Cr})$ was defined as the ratio between the sum of integrated intensities of ten diffraction lines $\left(\Sigma \mathrm{A}_{\mathrm{hkl}}\right)$ of the coating diagram, and of the same ten lines of a fully crystalline HA reference powder $\left(\Sigma \mathrm{A}_{\mathrm{hll}}^{0}\right)$ : $\mathrm{Cr}$ $=\left(\Sigma \mathrm{A}_{\mathrm{hkl}}\right) /\left(\Sigma \mathrm{A}_{\mathrm{hkl}}^{0}\right)$. The same approach was used to determine the ClA coating crystallinity. However, the (102) line used in crystallinity determination of HA is weak in ClA and it has a minor contribution in the crystallinity index; thus it was replaced by (201) line. Both coatings diagrams can be indexed in the hexagonal system indicating that a change of the structure of sprayed ClA powder has occurred. As we will see later, this structural modification is related to the alteration of the $\mathrm{ClA}$ crystals in the coatings and the formation of oxyapatite (OA) as well.
For both coatings, we noticed an increase of the full width at half maximum (FWHM) value of the diffraction lines compared to that of the initial powders (Figs. 4 and 5), which is generally assigned to two main phenomena: the decrease of the crystallite size, and the increase of the microstrain. In order to evaluate these contributions, Rietveld refinement analyses were performed using MAUD software. The crystallographic parameters determined for the HA and ClA initial powders and for the 12-run HA- and ClA-coatings are reported in Table $\mathbf{4}$ and Table $\mathbf{5}$, respectively. For HA- and ClA-coatings, we can notice both a significant increase in micro-strains and a decrease in crystallite size. However, these observations and the related calculations neglect an important cause of line broadening associated with the formation of heterogeneous solid solutions of oxyhydroxyapatite and oxy-chlorapatite, which would result in broadened diffraction lines, corresponding to the sum of unresolved diffraction peaks of individual crystalline domains considered as homogeneous. For the OClA this effect would result in a higher broadening of diffraction lines than for OHA, due to larger differences in unit-cell dimensions between OA and ClA [60]. The average unit-cell dimensions for $\mathrm{ClA}$ coatings can be compared to that of the powder considering that $\mathrm{b}=2 \mathrm{a}$ in the monoclinic $\mathrm{ClA}$ powder. The formation of solid solutions (OHA or OClA) can be related to a clear decrease of the a unit-cell dimensions noticed on the coatings. This effect appears

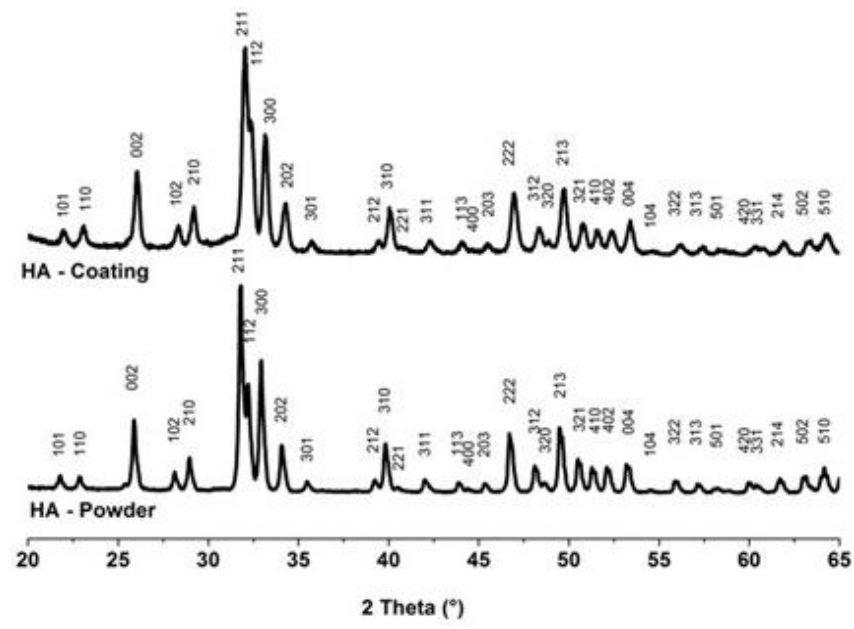

Fig. (4). X-ray diffraction patterns of HA powder and coating (12 spray runs). 
Table 4. Crystallographic parameters of HA powder and HA coating (12 spray runs). (The pattern obtained with Rietveld refinement of a $\mathrm{HA}$ coating is given as supportive material).

\begin{tabular}{|c|c|c|}
\hline Space group: $\mathbf{P 6} \mathbf{z}_{3} \mathbf{m}$ & HA-powder & HA-coating \\
\hline \hline $\mathrm{a}(\AA)$ & $9.4157(2)$ & $9.4107(2)$ \\
\hline $\mathrm{c}(\AA)$ & $6.8865(2)$ & $6.8748(2)$ \\
\hline Crystallites size $(\mu \mathrm{m})$ & $0.4025(171)$ & $0.2030(67)$ \\
\hline Microstrain $(\mathrm{rms})$ & $0.00058(2)$ & $0.00099(2)$ \\
\hline $\mathrm{R}_{\text {exp }}(\%)$ & 5.47 & 6.00 \\
\hline
\end{tabular}

Table 5. Crystallographic parameters of ClA powder and ClA coating (12 spray runs).

\begin{tabular}{|c|c|c|}
\hline Space group: $\mathbf{P}_{\mathbf{1}} \mathbf{c}$ & ClA-powder & ClA-coating \\
\hline \hline $\mathrm{a}(\AA)$ & $9.652(1)$ & $9.550(3)$ \\
\hline $\mathrm{b}(\AA)$ & $19.319(2)$ & $6.818(2)$ \\
\hline $\mathrm{c}(\AA)$ & $6.784(1)$ & - \\
\hline$\beta\left({ }^{\circ}\right)$ & $120.00(2)$ & $0.0747(20)$ \\
\hline Crystallites size $(\mu \mathrm{m})$ & $0.1467(39)$ & $0.00135(3)$ \\
\hline Microstrain $(\mathrm{rms})$ & $0.00106(3)$ & 5.85 \\
\hline $\mathrm{R}_{\exp }(\%)$ & 6.30 & \\
\hline
\end{tabular}

stronger for $\mathrm{OClA}$ due to the strong difference in unit-cell dimensions of $\mathrm{ClA}$ and $\mathrm{OA}$ just mentioned. However, in the case of ClA coatings, another possibility for the variations of the unit cell dimensions, compared to those of the $\mathrm{ClA}$ powder, would be the formation of a non-stoichiometric $\mathrm{ClA}$ at high temperature due to the release of $\mathrm{CaCl}_{2}[51]$.

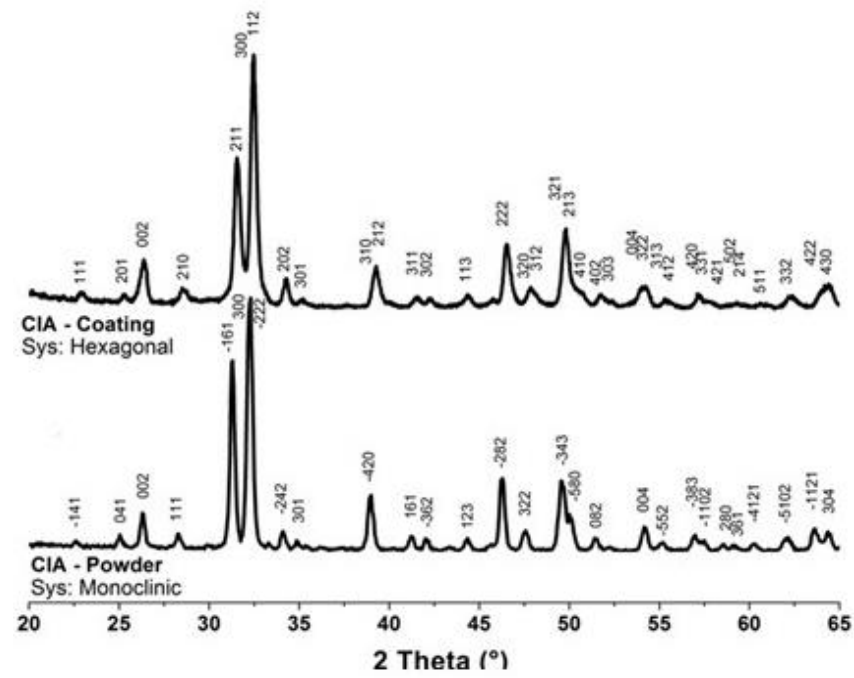

Fig. (5). X-ray diffraction patterns of ClA powder and coating (12 spray runs).

The calculated crystallinity ratio, determined according to the standard, was equal to $68 \%$ for HA-coating and to $98 \%$ for $\mathrm{ClA}$-coating. The ClA-coating showed a much higher crystallinity ratio than HA-coating, although it was not determined in the same way. This observation should not be only related to the amount of amorphous phase formed in the coatings. Other causes can produce crystallinity variations such as fast recrystallization of small apatite crystals from the melt or the amorphous phase, or the formation of solid solutions with OA.

The $\mathrm{Ca} / \mathrm{P}$ ratio of $\mathrm{HA}$ - and $\mathrm{ClA}$-coatings obtained after 12 spray runs was determined according to the ISO 13779-3: 2008 standard on a scraped and ground coating, which had been heated at $1000^{\circ} \mathrm{C}$ during $15 \mathrm{~h}$. The XRD patterns showed only apatite crystals for both HA- and ClA-coatings, indicating that plasma spraying using the LEPS system did not appear to alter the stoichiometry of the apatite.

\section{Vibrational Spectroscopy Analysis of the Coatings.}

Several additional characteristics of the apatite coatings are more difficult to determine using X-ray diffraction analyses: the main phase proportions and their distribution within the coating, and, more importantly, the amount of amorphous phase, which is not specifically considered in the ISO standard, although it could determine the coating behaviour in vitro and in vivo. A more accurate characterization of $\mathrm{HA}$ and $\mathrm{ClA}$ powders and the related plasma sprayed apatite coatings can be proposed, using vibrational spectroscopies [61], Fourier transform infrared spectroscopy and Raman spectroscopy, with a special focus on Raman micro-spectroscopy imaging on $\mathrm{HA}$ - and $\mathrm{ClA}$ coatings. 


\section{FTIR Spectroscopy Characterization}

Both initial HA and ClA powders and scraped HA- and ClA-coatings were analysed by transmission Fourier transform infrared (FTIR) spectroscopy (Nicolet 5700 spectrometer, ThermoElectron) using $\mathrm{KBr}$ pellets. We examined especially the 1100-950 $\mathrm{cm}^{-1}\left(v_{1} \mathrm{PO}_{4}\right.$ and $\left.v_{3} \mathrm{PO}_{4}\right)$ and $600-450 \mathrm{~cm}^{-1}\left(v_{4} \mathrm{PO}_{4}\right)$ domains, corresponding to the different phosphate vibration bands. In these domains, FTIR spectra of both HA- and ClA-coatings Figs. (6 and 7) showed broader and less resolved bands than that of the initial powders. This phenomenon can be related to a decrease in crystallinity. The enhanced relative intensity of bands observed in the $v_{2} \mathrm{PO}_{4}$ domain (434 and $471 \mathrm{~cm}^{-1}$ ), in the spectrum of the HA coating, can be correlated to the splitting of the $v_{1} \mathrm{PO}_{4}$ band and the decrease in the relative intensity of the $\mathrm{OH}$ bands at 3572 and $630 \mathrm{~cm}^{-1}$ (Fig. 6) which have been shown to correspond to the formation of oxyapatite [61]. Although less visible than in HA, the formation of oxyapatite is also apparent on FTIR spectra of ClA coatings (Fig. 7) which exhibit lines with a higher intensity in the ${ }_{2} \mathrm{PO}_{4}$ domain than the starting powder.

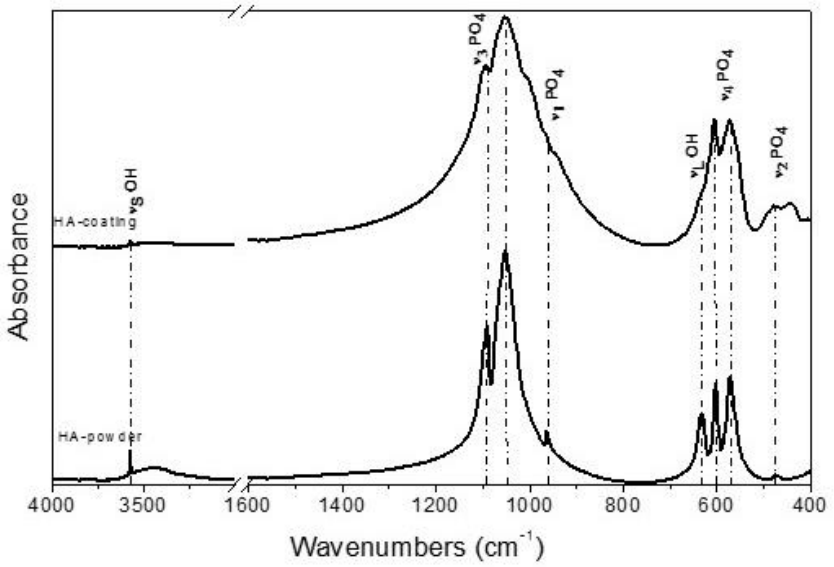

Fig. (6). FTIR spectra of HA powder and coating.

\section{Raman Spectroscopy Characterization}

All phases detected in a plasma-sprayed coating of HA can theoretically be distinguished by Raman spectroscopy, especially the most important ones, in some instances with better sensitivity than according to XRD analyses [52]. In addition, Raman scattering imaging allows local investigation of the coating's heterogeneity $[52,62]$. The $v_{1} \mathrm{PO}_{4}$ domain, with strong thin lines, seems well adapted for imaging $[6,63]$. The amorphous calcium phosphate (ACP) especially is characterized by a broad Raman line around 950 $\mathrm{cm}^{-1}$ and all crystalline phases show lines distinct from that of apatite at $961 \mathrm{~cm}^{-1}$. The xyapatite (OA), rather difficult to distinguish by other methods, exhibits very specific Raman scattering lines at about $951 \mathrm{~cm}^{-1}$ and $966 \mathrm{~cm}^{-1}$ [64]. The only phase that cannot be detected in this domain is $\mathrm{CaO}$.

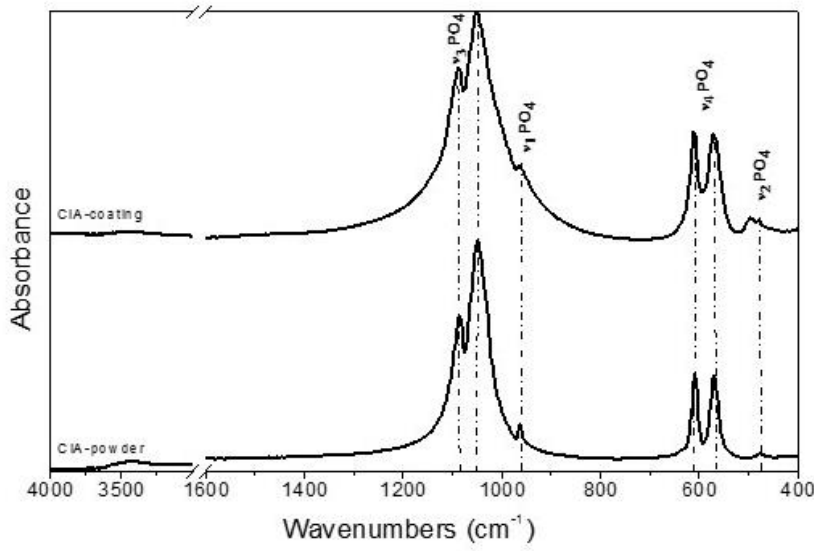

Fig. (7). FTIR spectra of ClA powder and coating.

Both initial HA and $\mathrm{ClA}$ powders and the as-prepared HA- and ClA-coatings were analysed by Raman spectroscopy in the range of $100-1200 \mathrm{~cm}^{-1}$ and $3500-3600$ $\mathrm{cm}^{-1}$ (Horiba Jobin-Yvon HR 800 spectrometer equipped with a helium-neon laser: $\lambda=632.8 \mathrm{~nm}$ ). The quantitative evaluation of the components of the $v_{1} \mathrm{PO}_{4}$ band was performed using LabSpec 5 software (Horiba). The $v_{1} \mathrm{PO}_{4}$ band Raman spectra were decomposed according to the same protocol for all the samples in order to facilitate their comparison [52]: a baseline correction was performed on each spectrum. Peak positions and some curve-fitting parameters were recorded and used as initial input in the curve-fitting program. Iterations continued until the best fit was obtained.

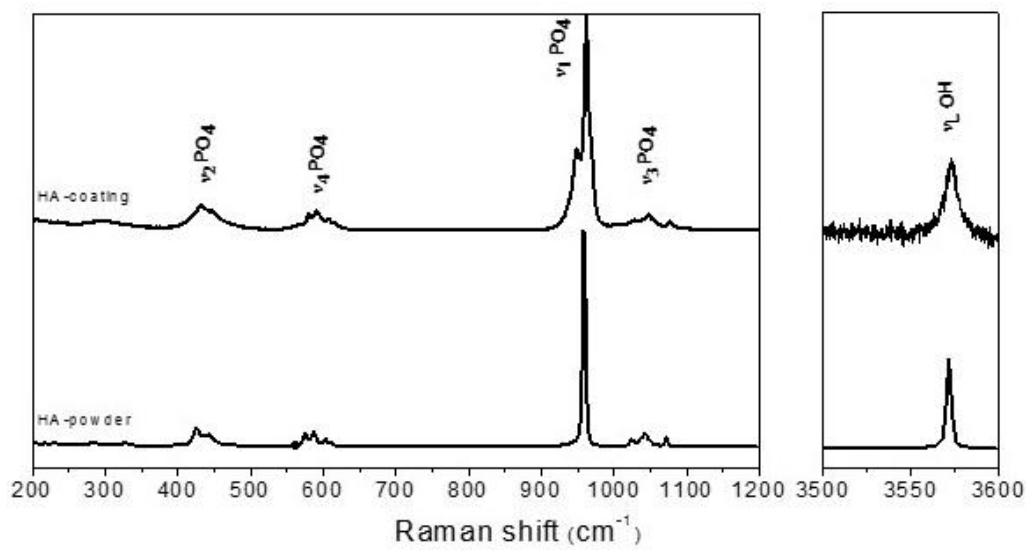

Fig. (8). Raman spectra of HA powder and coating. 


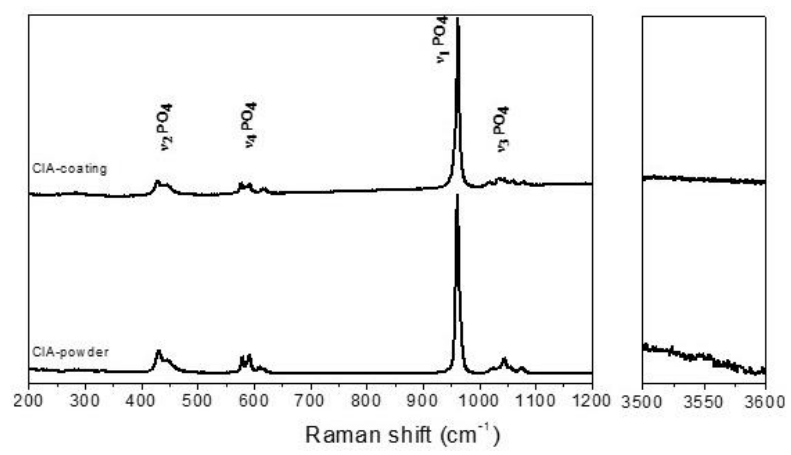

Fig. (9). Raman spectra of ClA powder and coating.

The Raman spectra of HA and ClA scrapped coatings are presented in Figs. (8) and (9) together with those of the initial powders. The most intense Raman line, $v_{1} \mathrm{PO}_{4}$, appeared the most altered after spraying. The integrated intensity of the different contributing sub-bands has been determined to estimate quantitatively the changes induced by spraying. The resulting curve-fittings are presented in Figs. (10) and (11) for HA- and ClA-coatings respectively. The detection of oxyapatite phase in both coatings confirmed the results obtained by FTIR spectroscopy; however, the proportion of OA appears always significantly less important in ClA than in HA coatings. The same observation is true for the amorphous phase.

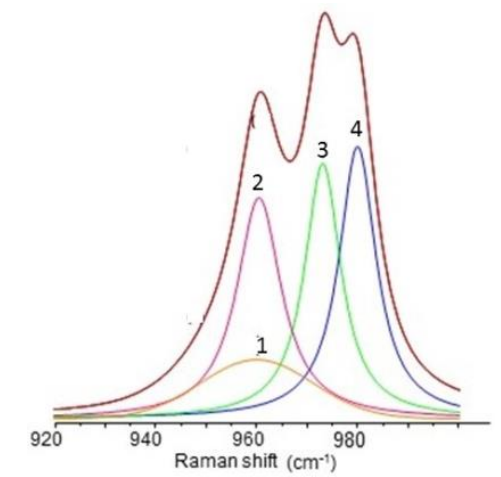

Fig. (10). A-Gaussian-Lorentzian curve fitting of the $v_{1} \mathrm{PO}_{4}$ Raman stretching domain of HA coatings (20 spray runs), with the LEPS plasma gun. (1) ACP: amorphous calcium phosphate; (2) and (4) OA: oxyapatite; (3) HA: hydroxyapatite.

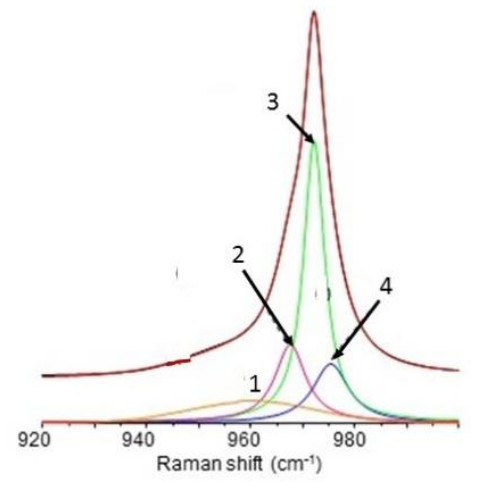

Fig. (11). A-Gaussian-Lorentzian curve fitting of the $v_{1} \mathrm{PO}_{4}$ Raman stretching domain of ClA coatings (20 spray runs), with the LEPS plasma gun. (1) ACP: amorphous calcium phosphate; (2) and (4) OA: oxyapatite; (3) ClA: Chlorapatite.
An accurate mapping of the different phases in apatite coatings can be obtained by micro-Raman imaging involving curve fitting in the $v_{1} \mathrm{PO}_{4}$ domain, extraction of the characteristic line(s) associated with specific phases, and of their relative intensities [52]. It should be noticed that at this stage, without accurate standardization, and due to uncertainties in decomposition results. The data do not represent the real content of phases present in the coating but offer a base for visualizing the phase distribution in a first semi-quantitative approach. Figs. (12) and (13) show the main constituents distributions, i.e. $\mathrm{HA}$ or $\mathrm{ClA}$, OA and $\mathrm{ACP}$, in the cross section of HA and ClA coatings. The heterogeneity in the distribution of the constituents is immediately apparent. Domains with a high content in HA appear to be embedded in an amorphous phase acting as a binder. These observations are consistent with other descriptions of phenomenon occurring during plasma spraying $[4,5,63,65]$. The nodules of HA, which appear as well delimited zones, are believed to correspond to the unmelt cores of the splats. In some cases smaller HA domains grouped in a zone may appear, corresponding possibly to the crash and dispersion into smaller particles of the solid core of splats impacting the substrate or to recrystallization of HA from the melted or amorphous phase. The OA rich domains are distributed more uniformly than the HA nodules and do not form well-defined zones with dominant concentrations. This distribution could result of a recrystallization process in the melted part of the splats, possibly associated with a direct formation of $\mathrm{OA}$ in the unmelt cores.

For ClA coatings the layered structure of the coating related to the splat accumulation is more apparent than in HA coatings, especially in the ACP mapping. The ClA domains appear elongated and rather diffuse, indicating a better spreading of the splats; they are surrounded by the amorphous phase. The OA seems more homogeneously distributed at the surface of $\mathrm{ClA}$ domains or within amorphous domains; in these domains, zones very poor in $\mathrm{ClA}$ and rich in OA can be clearly observed, suggesting that $\mathrm{AO}$ forms mainly in a recrystallization processes of the molten phase or the amorphous phase.

Therefore, Raman micro-spectroscopy can be used as a routine non-destructive tool to obtain rapid analysis of the composition of apatite coatings and even of different domains of a splat. This technique could be adapted for the chemical characterization of the coating directly on 
biomedical implants. Image analyses could then be used to describe the coating characteristics with accuracy.

\section{Surface Roughness}

The average roughness of the $\mathrm{ClA}$ and HA coatings was determined by optical interferometry (Zygo) as the average of four measurements. The surface arithmetic roughness of $\mathrm{HA}$ and $\mathrm{ClA}$ coatings ( $\mathrm{Ra}$ ) was determined as a function of the number of spray runs Fig. (14). Ra increases strongly after the first run and reaches rapidly a constant value depending on the nature of the apatite: it is always higher in $\mathrm{HA}$ coatings than in $\mathrm{ClA}$ coatings. The increase of $\mathrm{Ra}$ is commonly observed and has been related to the structure of splats generally smaller at the fringe and larger in the centre [66]. These data indicate that HA splats are globally thicker than $\mathrm{ClA}$ ones, and seem consistent with the variations of the coating thickness according to the number of runs. The difference between $\mathrm{HA}$ and $\mathrm{ClA}$ coatings could be due, in part, to the alteration, already mentioned, of the particle size related to the chlorinating treatment.

The coating surfaces and cross-sections were studied by scanning electron microscopy (SEM). The coating crosssections were carbon coated, then SEM micrographs were recorded in the secondary electron mode using a LEO 435 VP microscope. The typical surface morphologies of the assprayed HA- and ClA-coatings (12 spray runs) are presented as supportive materials.

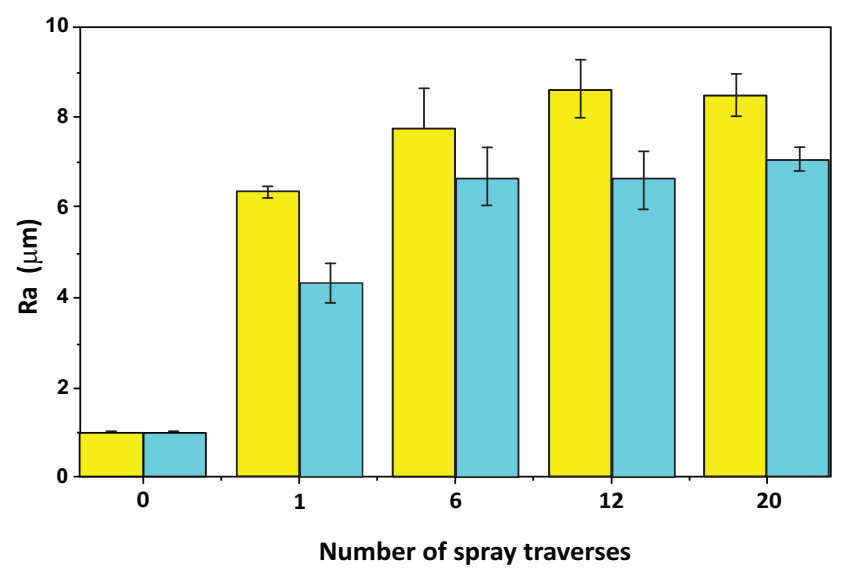

Fig. (14). Surface roughness of the coatings vs. number of sprayruns ( 0 : initial roughness of Ti plate).

\section{MECHANICAL PROPERTIES}

Several methods can be used to determine the adherence of a coating to its substrate. Concerning calcium phosphate coatings, an adherence measurement test was standardized (ASTM C633-01, ISO 13779-4) and the results obtained according to this procedure will be first presented. Among other methods used, the three point bending with a stiffener has also been applied and will be discussed.
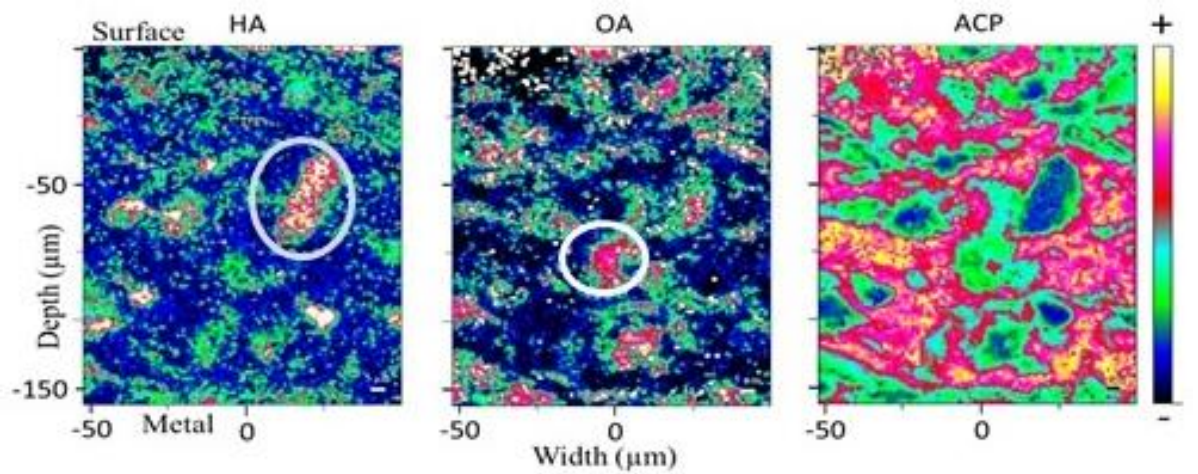

Fig. (12). Raman spectroscopy mappings of HA, OA and ACP in hydroxyapatite coatings. Light blue oval: domain rich in HA, poor in ACP and with a little OA, tentatively associated with an unmelt core of a splat. White circle: domain rich in OA, poor in HA, with some ACP, attributed to the recrystallization of a molten domain or recrystallization of solid ACP phase.
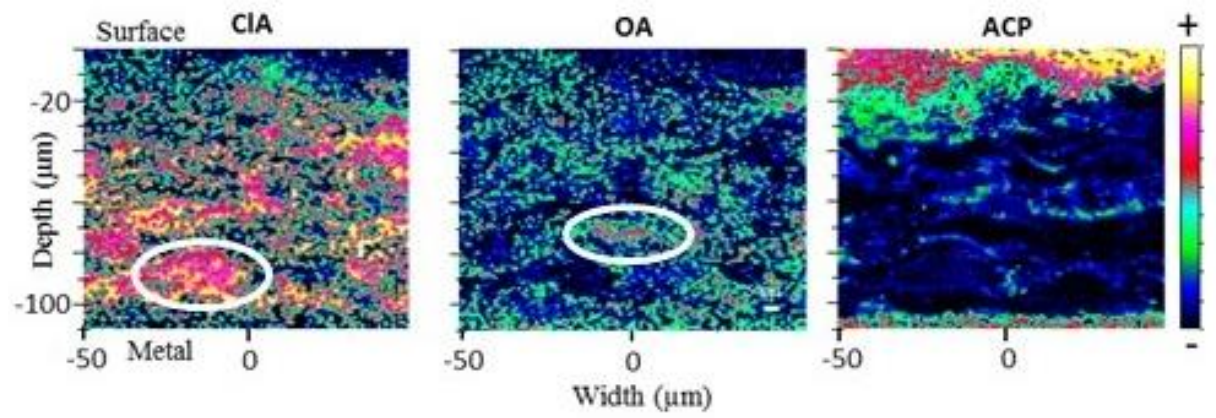

Fig. (13). Raman spectroscopy mappings of $\mathrm{ClA}$, OA and ACP in chlorapatite coatings. Light blue oval: domain rich in $\mathrm{ClA}$, poor in $\mathrm{ACP}$ and OA, tentatively associated with an unmelt core of a splat. White circle: domain rich in OA, poor in HA, within two ACP layers, attributed to the recrystallization of a molten domain or of solid ACP phase. The layered structure of the splats is clearly visible on ACP maps (the top surface is corrupted by the spectra of the embedding resin). 


\section{Tensile Strength (ASTM C633-01, ISO 13779-4)}

Test samples were made on $25 \mathrm{~mm}$ disks coated with HA or ClA (12 spray runs). These coated disks were glued to a dummy cylinder with the same diameter with FM1000 glue, (Cytec, NJ, USA) applied at $200^{\circ} \mathrm{C}$ for 90 to 100 minutes. The ultimate tensile strength of the assembly was determined on an Instron instrument, without pre-loading at a traction rate of $1 \mathrm{~mm} /$ minute. The data obtained (mean of six measurements) are presented in Table 6. There was no significant difference between $\mathrm{ClA}$ and HA coatings. The failure appeared mainly cohesive for HA coupons (it occurred at the interface between the coating and the substrate), and it was mixed cohesive (at $80 \%$ ) and adhesive for $\mathrm{ClA}$ coupons.

Table 6. Tensile strength of the coatings obtained at 12 spray runs

\begin{tabular}{|c|c|}
\hline Coating & Tensile bond strength (MPa) \\
\hline \hline HA & $8.9 \pm 1.5$ \\
\hline ClA & $8.2 \pm 2.2$ \\
\hline
\end{tabular}

The ultimate loads observed are in the lower range of those reported for HA coatings obtained by plasma spraying [65]. The main drawback of this basic standardized test is the diffusion of the glue in the porous coating and its limitation to rather thick coatings (above $0.38 \mathrm{~mm}$ ). Other measurements were performed especially the three point bending with stiffener.

\section{Three Point Bending Test with Stiffener}

This test was developed particularly by A. Roche et al. [67] and lead to the ISO 14679-1997 standard. It is designed to determine adhesive or cohesive properties of paints, varnish and others coatings. A stiffener epoxy resin (Araldite ${ }^{\circledR}$ AW134B with HV997 hardener) is cured onto the coated substrate in accordance with the standard to generate a stress concentration at the interface substrate-deposit. Such loading is known to produce mainly shear stress at the substrate/coating interface and appears more consistent with the surgical use of coated prosthesis. The determination of the critical shear stress of the interface requires, without considerations to the actual geometry of the sample, to know the mechanical properties of all the materials implied in the elaboration of the samples: substrate, coating, and bulk stiffener Young's modulus, as well as the thickness and elastic properties of a possible interphase between the coating and the stiffener. Once these parameters are determined, critical shear stress and critical strain energy release rate of the substrate coating interface can be determined from experimentally measured critical load, thanks to analytical and/or numerical models [68]. This complexity led us, as many authors $[69,70]$ to consider this practical adhesion test as a comparative test, considering critical load $\mathrm{F}_{\max }$ an indicator of adhesion.

The tests were performed on corundum-blasted titanium coupons plasma-sprayed at 12 spray runs. The stiffener was casted in a silicon mould, directly on coated samples. The mechanical test apparatus used in this experiment consists in an electromechanical Instron test machine fitted with a load cell capacity of $500 \mathrm{~N}$. The crosshead speed is set to $0.5 \mathrm{~mm}$. $\min ^{-1}$. A schematic illustration of the testing conditions is given as supportive material. Ten samples were successfully tested for ClA coatings, only eight for HA and two of them had the rupture of the stiffener itself. Load versus displacement curves are displayed on Fig. (15). To check the quality of the stiffener, we measured the stiffness of the sample. It was found to be $319 \pm 16.9 \mathrm{~N} . \mathrm{mm}^{-1}$ for HA coatings and $305 \pm$ 9.83 N.mm ${ }^{-1}$ for CIA coatings. These preliminary results confirmed the good quality of the polymeric stiffener.

An abrupt decrease in load-displacement behaviour was observed beyond $\mathrm{F}_{\max }$. The maximum load $\mathrm{F}_{\max }$ achieved before rupture of the substrate-coating interface, thanks to the geometrical effect generated by the stiffener, is the indicator of the practical adhesion. For HA, $\mathrm{F}_{\max }=165 \pm$ $30.7 \mathrm{~N}(18.6 \%)$, and for ClA, $\mathrm{F}_{\max }=128 \pm 7.92 \mathrm{~N}(6.16 \%)$. Coatings exhibited mixed modes of failure (cohesive and adhesive). By image analysis on Energy-dispersive X-ray spectroscopy (EDX) maps, adhesive failure was estimated to be closed to $65 \%$ for both HA and ClA deposits. (EDX maps are given as supportive material)

\section{DISCUSSION}

The data reveal some differences between $\mathrm{HA}$ and $\mathrm{ClA}$ coatings obtained in similar deposition conditions with powders showing slightly different characteristics:

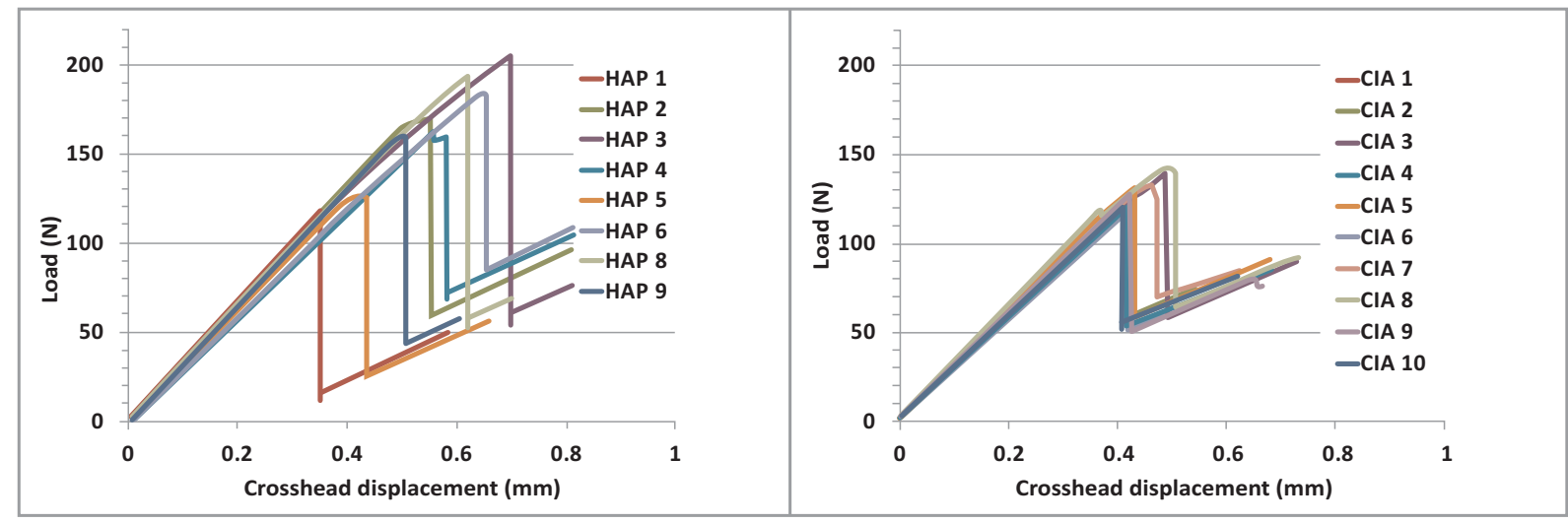

Fig. (15). three point bending tests loading curves for HA (left) and ClA (right) coatings. 
- Formation of oxyapatite occurs in both coatings but ClA coatings exhibit much lower OA contents than HA.

- ACP content is also lower in ClA coatings compared to HA ones.

- Thickness of the coatings for the same number of spray runs is higher for HAp than for ClAp;

- Surface roughness is higher in HA than in ClA

- Mechanical properties appear also slightly different, showing lower strength in ClA than in HA coatings in a three point bending test with stiffener, although adherence tests according to the ISO standard 13779-4 did not revealed significant differences.

\section{HA and ClA Powder Characteristics}

The different physical characteristics of the HA and ClA coatings, for identical spray conditions, could be related to slight changes in the powder characteristics and specific differences in the apatites involved. The chlorination treatment was expected to preserve the crystal size and grain characteristics. Actually, the reverse treatment (the hydroxylation of $\mathrm{ClA}$ ) on monocrystals allowed the preparation of HA monocrystals and its crystal structure determination [71], this ability of high temperature ion exchange reactions to preserve the crystalline structure having been recently confirmed [72]. This is not observed in our chlorination experiments and a significant decrease of the crystal size of the initial HA was observed during its transformation into $\mathrm{ClA}$. The role of the change in unit-cell volume between HA and ClA could be involved, although it represents only $3.6 \%$ of the total volume. It shall be noticed, however, that the change in unit cell dimensions between $\mathrm{HA}$ and $\mathrm{ClA}$ involves a decrease of the c dimension and an increase of the a dimension. These opposite variations in partly sintered grains could lead to a rupture of the initial crystals and eventually of the grains. The reduction of roughness in ClA coatings compared to HA ones, even for one spray run, indicates a better spreading of the splats, possibly due to a lesser amount of matter and/or higher content of liquid phase and/or a lower viscosity. The slightly lower melting point of $\mathrm{ClA}\left(1530^{\circ} \mathrm{C}\right)$ compared to that of HA $\left(1570^{\circ} \mathrm{C}\right)$, according to phase diagrams, together with a smaller grain and crystal size, could facilitate its melting within sprayed grains, although other considerations on heat transfers in the plasma flame have also to be taken into account [73].

\section{Oxyapatite Content}

The strong differences between Raman spectra of HA and $\mathrm{OA}$ have been assigned to variations of the local environments of phosphate ions, i.e. $\mathrm{OH}^{-}$ions in $\mathrm{HA}$ and lattice vacancies or $\mathrm{O}^{2-}$ ions in OA. Involving a, correlative alterations of the vibrational energy level of the phosphate ion in the apatite lattice. The formation of OA in HA coatings is generally attributed to the dehydration of HA during heating. Actually, $\mathrm{OA}$ is not considered to exist as a separate phase but as a solid solution, OHA (oxyhydroxyapatite). Raman spectra do not allow to discriminate easily between solid solution of OHA and mixtures of HA and OA phases. However, Raman mapping reveals micro-domains containing both $\mathrm{HA}$ and $\mathrm{OA}$ environments, thus supporting the existence of solid solutions. In addition, very strong spatial variations are evidenced indicating a strong heterogeneity. The formation of OA environments appears as an intermediate stage before the decomposition of HA into TTCP and TCP takes place. A second process of formation of OA environments is due to the recrystallization of apatite in a melt practically deprived of $\mathrm{OH}^{-}$ions. The existence of domains very rich in $\mathrm{OA}$ and very poor in HA are consistent with this recrystallization process.

The formation of $\mathrm{OA}$ in $\mathrm{ClA}$ coatings is rather puzzling as there is no precursor of oxygenated species. Thus in ClA coatings the formation of $\mathrm{OA}$ involves necessarily a reaction with a contaminant. A reaction may be proposed with residual water molecules remaining in the ClA powder, which was stored and manipulated in air. In fact, this is the reverse reaction of the chlorination synthesis, which has been used to synthesize hydroxyapatite monocrystals:

$$
\begin{aligned}
& 2 \mathrm{H}_{2} \mathrm{O}+\mathrm{Ca}_{10}\left(\mathrm{PO}_{4}\right)_{6} \mathrm{Cl}_{2} \\
& \mathrm{Ca}_{10}\left(\mathrm{PO}_{4}\right)_{6} \mathrm{O}+\mathrm{H}_{2} \mathrm{O}+\mathrm{HCl}
\end{aligned} \mathrm{Ca}_{10}\left(\mathrm{PO}_{4}\right)_{6}(\mathrm{OH})_{2}+\mathrm{HCl} \underset{(4)}{\leftrightarrow}
$$

Such a reaction involves the formation of $\mathrm{HA}$ as an intermediate phase. Although there is no detection of $\mathrm{OH}^{-}$ ions in the ClA coatings by Raman or FTIR spectroscopy, this reaction could occur in the plasma or on the surface of the coupon during cooling in air.

A second possible reaction would be the direct oxidation of $\mathrm{ClA}$ with $\mathrm{O}_{2}$ from air:

$\mathrm{O}_{2}+\mathrm{Ca}_{10}\left(\mathrm{PO}_{4}\right)_{6} \mathrm{Cl}_{2} \leftrightarrow \mathrm{Ca}_{10}\left(\mathrm{PO}_{4}\right)_{6} \mathrm{O}+\mathrm{Cl}_{2}$

although this analogue of Deacon's reaction [74] has never been reported in ClA. This reaction would occur preferably at the surface of splats during the cooling stage, when in contact with the air.

Other reactions might be possible between $\mathrm{TiO}_{2}$ at the surface of the substrate and ClA. However, OA is distributed in the coating thickness and does not localize especially in close proximity to the titanium surface. OA rich domains are always observed in domains isolated from $\mathrm{ClA}$ rich ones, with no clear gradation, suggesting a preferential formation of $\mathrm{OA}$ in a recrystallization process from the molten phase, which would facilitate oxygen diffusion and reaction. The mode of formation of OA in ClA coatings, which implies reactions with contaminants, explains why these contain significantly less OA than the HA ones, where OA formation is a part of the thermal degradation.

\section{Amorphous Phase Content}

Concerning the formation of ACP, the Raman spectroscopic data appear more reliable than the crystallinity measurements done by XRD following standards. As already mentioned before, several causes may be behind the decrease in XRD crystallinity observed in the coatings, of which ACP formation is only one. On the contrary, the significant shift in the Raman $v_{1} \mathrm{PO}_{4}$ of ACP, compared to that of apatite HA or ClA $\left(-12 \mathrm{~cm}^{-1}\right)$, appears as a distinctive characteristic of the amorphous phase. However the broadness of the amorphous $\mathrm{PO}_{4}$ lines in Raman spectra and the superimposition with an $\mathrm{OA}$ line, do not allow a very 
accurate quantitative evaluation. The formation of ACP is assigned to the rapid cooling of the molten grain reaching the surface. However, a recrystallization process is supposed to either happen during the cooling of the splat or during an additional upper layer spray run, involving a local re-heating of an underlying amorphous phase. Thus, a difference in ACP content could be related to different ratios of molten phases and/or different rates of recrystallization. All these phenomena are related to heat transfer in the plasma or in the coating, which are difficult to evaluate and control, although simulations have been proposed [73]. Several spray parameters such as the angle of spraying; the spray distance and the plasma gas flow rate have been shown to determine the amorphous content of coatings [25]. However, these parameters were maintained constant in this study. A crucial parameter seems to be the particle size, which is related to strong amorphous phase variations [25]. The characteristics of ClA powders compared to HA ones (lower melting point, smaller grain size and crystal size) should favour the formation of coatings with a higher content in amorphous phase, which is not observed. Therefore, the recrystallization rate could be a determining factor in the ACP content in these experiments.

Different recrystallization processes may occur in coatings: crystal formation directly from the melt or in solid state, from the ACP phase. The recrystallization in the melt is expected to be a faster process, although it can be interrupted by the rapid cooling and solidification of the splat. Recrystallization from the melt could be easier in the case of $\mathrm{ClA}$ as it does not involve intermediate phases like those theoretically observed in HA recrystallization according to phase diagrams. The recrystallization from the amorphous solidified phase would then follow and may occur at a rather low temperature. In HA coatings for example, the recrystallization of ACP has been observed at about $700^{\circ} \mathrm{C}$ [75]. The low recrystallization temperature could also occur when a new hot layer is deposited on a cold one, due to the low thermal conductivity of apatites.

\section{Mechanical Properties}

The difference in mechanical properties between ClA and HA coatings is especially apparent in the three point bending test with stiffener, which seems more reliable than the standardized test. The adhesive strength of coatings has been correlated to the porosity of the coatings, the presence of cracks related to stresses due to differences in thermal coefficient expansion, and its composition. In wet media, rehydration of the coating, inducing cracks, has been identified as a crucial parameter in the degradation of mechanical properties. Chemical interactions between the coating and the oxide layer of the substrate have been suggested, but their role in the adhesion has not been clearly identified. Concerning the phase content, it appears that a high amount of ACP, as well as a high amount of crystalline phase, is not favourable [76]. The weaker strength of ClA coatings could thus be related to too high a crystallinity.

\section{CONCLUSION}

The main characteristics of ClA compared to HA coatings is a higher content in apatite and a lower content in amorphous calcium phosphate and oxyapatite. It is probable that slight modifications in the coating process would permit to limit even further the formation of $\mathrm{OA}$ in $\mathrm{ClA}$ coatings, especially a careful elimination of water from the ClA powder, although the role of OA in coatings is not known and this phase should not behave differently from other apatites. The expected advantage of ClA coatings would be a lesser degradation in vivo. A persisting problem remains the poor adhesion of the ClA coating on titanium substrates. In vivo experiments have been realized and the explants are currently examined. The first results show a direct attachment of bone to the coating surface, as it is usually found for this kind of coating. These results will be published in a forthcoming report.

\section{SUPPLEMENTARY MATERIALS}

Supplementary material is available on the publisher's web site along with the published article.

\section{CONFLICT OF INTEREST}

The authors confirm that this article content has no conflict of interest.

\section{ACKNOWLEDGMENTS}

This study was carried out under a MNT ERA-Net Project named NANOMED. The authors gratefully thank the Midi-Pyrénées region (MNT ERA Net Midi-Pyrénées Région, NANOMED2 project) and the Institute National Polytechnique de Toulouse (BQR INPT 2011, BIOREVE project) for supporting this research work, especially the financial support for research carried out in the CIRIMAT and the LGP laboratories (France), and the Basque government and Tratamientos Superficiales Iontech, S.A. for their financial and technical support under the IG2007/0000381 grant for the development of the LEPS device and deposition of the coatings carried out in InasmetTecnalia. The French industrial collaborators (TEKNIMED SA and 2PS SA) were financed by the OSEO programs.

\section{REFERENCES}

[1] J.B. Brunski "Metals", in Biomaterials Science: An Introduction to Materials in Medicine, B.D. Ratner, A.S. Hoffman, F.J. Schoen, J.E. Lemons, Eds. New York: Elsevier Inc., 2004, pp. 137-153.

[2] M. Niinomi, "Metallic biomaterials", J. Artif. Organs, vol. 11, pp. 105-110, 2008

[3] G. Wang, H. Zreiqat, "Functional coatings or films for hard-tissue applications", Materials, vol. 3, pp. 3994-4050, 2010.

[4] L. Sun, C.C. Berndt, K.A. Gross, A. Kucuk, "Material fundamentals and clinical performance of plasma-sprayed hydroxyapatite coatings: A review", J. Biomed. Mater. Res. (Appl. Biomater.), vol. 58, pp. 570-592, 2001.

[5] R.B. Heimann, "Thermal spraying of biomaterials", Surf, Coat. Technol., vol. 201, pp. 2012-2019, 2006.

[6] S.R. Paital, N.B. Dahotre, "Calcium phosphate coatings for bioimplant applications: Materials, performance factors, and methodologies", Mater. Sci. Eng. R, vol. 66, pp. 1-70, 2009.

[7] R.A. Surmenev, "A review of plasma-assisted methods for calcium phosphate-based coatings fabrication", Surf. Coat. Technol., vol. 206, pp. 2035-2056, 2012

[8] R.A. Surmenev, M.A. Surmeneva, A.A. Ivanova, "Significance of calcium phosphate coatings for the enhancement of new bone osteogenesis - A review", Acta Biomater., vol. 10, pp. 557-579, 2014. 
[9] C.C. Berndt, G.N. Haddad, K.A. Gross, "Thermal spraying for bioceramic applications", Materials Forum, vol. 14, pp. 161-173, 1990.

[10] K. de Groot, "Hydroxyapatite as coating for implants", Interceram, vol. 4, pp. 38-41, 1987.

[11] K. de Groot, R.G. Geesink, C.P. Klein, P. Serekian, "Plasma sprayed coatings of hydroxyapatite", J. Biomed. Mater. Res., vol. 21, pp. 1375-1381, 1987.

[12] K.A. Thomas, "Hydroxyapatite coatings", Orthopedics, vol. 17, pp. 267-278, 1994.

[13] K. Soballe, E.S. Hansen, H. Brockstedt-Rasmussen, C.M. Pedersen, C. Bünger, "Hydroxyapatite coating enhances fixation of porous coated implants", Acta Orthop. Scand., vol. 61, pp. 299306, 1990.

[14] L. Pawlowski, Ed. The science and engineering of thermal spray coating. Chichester, John Wiley \& Sons, 2008.

[15] S. Overgaard, "Calcium phosphate coatings for fixation of bone implants", Acta Orthop. Scand., vol. 297, no. 71, pp. 1-74, 2000.

[16] J. Cizek, K.A. Khor, "Role of in-flight temperature and velocity of powder particles on plasma sprayed hydroxyapatite coating characteristics", Surf. Coat. Technol., vol. 206, pp. 2181-2191, 2012.

[17] K.A. Gross, C.C. Berndt, "Thermal processing of hydroxyapatite for coating production", J. Biomed. Mater. Res., vol. 39, pp. 580587, 1998.

[18] L.G. Ellies,, D.G. Nelson, J.D. Featherstone, "Crystallographic changes in calcium phosphates during plasma-spraying", Biomaterials, vol. 13, pp. 313-316, 1992.

[19] B.C. Wang, E. Chang, C.Y. Yang, D. Tu, C.H. Tsai, "Characteristics and osteoconductivity of three different plasmasprayed hydroxyapatite coatings", Surf. Coat. Technol., vol. 58, pp. 107-117, 1993.

[20] R. McPherson, N. Gane, T.J. Bastow, "Structural characterization of plasma-sprayed hydroxylapatite coatings", J. Mater. Sci. Mater. Med., vol. 6, pp. 327-334, 1995

[21] C.Y. Yang, B.C. Wang, E. Chang, J.D. Wu, "The influence of plasma spraying parameters on the characteristics of hydroxyapatite coatings: A quantitative study", J. Mater. Sci. Mater. Med., vol. 6, pp. 249-257, 1995.

[22] J.E. Dalton, S.D. Cook, "In vivo mechanical and histological characteristics of HA-coated implants vary with vendor", $J$. Biomed. Mater. Res., vol. 29, pp. 239-245, 1995.

[23] M. Roy, A. Bandyopadhyay, S. Bose, "Induction plasma sprayed nano hydroxyapatite coatings on titanium for orthopaedic and dental implants", Surf. Coat. Technol., vol. 205, pp. 2785-2792, 2011.

[24] K.A. Khor, R. Kumar, P. Cheang, "Process-phase-properties relationship in radio frequency (RF) plasma synthesized hydroxyapatite (HA)", Surf. Coat. Technol., vol. 177-178, pp. (2004) 740-746, 2004

[25] K.A. Gross, C.C. Berndt, H. Heimann, "Amorphous phase formation in plasma-sprayed hydroxyapatite coatings", J. Biomed. Mater. Res., vol. 39, pp. 407-414, 1998

[26] R.Z. LeGeros, R. Zheng, R. Kijkowska, D. Fan, J.P. LeGeros, "Variations in composition and crystallinity of hydroxyapatite (Ha) preparations", in Symposium Characterization and performance of calcium phosphate coatings for implants, Miami, USA, 1994, pp. 43-53.

[27] J.D. de Bruijn, Y.P. Bovell, C.A. van Blitterswijk, "Structural arrangements at the interface between plasma sprayed calcium phosphates and bone", Biomaterials, vol. 15, pp. 543-550, 1994.

[28] C.P. Klein, A.A. Driessen, K. de Groot, A. van den Hooff, "Biodegradation behavior of various calcium phosphate materials in bone tissue", J. Biomed. Mater. Res., vol. 17, pp. 769-784, 1983.

[29] W.C. Xue, X.Y. Liu, X.B. Zheng, C.X. Ding, "Effect of hydroxyapatite coatings crystallinity on dissolution and osseointegration in vivo", J. Biomed. Mater. Res. A, vol. 54, pp. 553-561, 2005.

[30] S. Overgaard, U. Bromose, M. Lind, C. Bünger, K. Soballe, "The influence of crystallinity of the hydroxyapatite coating on the fixation of implants", J. Bone. Joint. Surg. B, vol. 81, pp. 725-731, 1999.

[31] E.A. Bonfante, L. Witek, N. Tovar, M. Suzuki, C. Marin, R. Granato, P.G. Coelho, "Physicochemical characterization and in vivo evaluation of amorphous and partially crystalline calcium phosphate coatings fabricated on Ti-6Al-4V implants by the plasma spray method", Int. J. Biomater., vol. Article ID 603826, p. 8, 2012, http://www.hindawi.com/journals/ijbm/2012/603826/

[32] H. Wang, N. Eliaz, Z. Xiang, H.-P. Hsu, M. Spector, L.W. Hobbs, "Early bone apposition in vivo on plasma-sprayed and electrochemically deposited hydroxyapatite coatings on titanium alloy", Biomaterials, vol. 27, pp. 4192-4203, 2006.

[33] R. Bidar, P. Kouyoumdjian, E. Munini, G. Asencio, "Long-term results of the ABG-1 hydroxyapatite coated total hip arthroplasty: Analysis of 111 cases with a minimum follow-up of 10 years", Orthop. Traumatol. Surg. Res. vol. 95, pp. 579-587, 2009.

[34] D.E. MacDonald, F. Betts, M. Stranick, S. Doty, A.L. Boskey, "Physicochemical study of plasma-sprayed hydroxyapatite-coated implants in humans", J. Biomed. Mater. Res., vol. 54, pp. 480-490, 2001 .

[35] R. Junker, P.J.D. Manders, J. Wolke, Y. Borisov, J.A. Jansen, "Bone-supportive behavior of micro-plasma-sprayed $\mathrm{CaP}$-coated implants: mechanical and histological outcome in the goat", Clin. Oral. Impl. Res., vol. 21, pp. 189-200, 2010.

[36] R. Junker, P.J.D. Manders, J. Wolke, Y. Borisov, J.A. Jansen, "Bone reaction adjacent to micro-plasma-sprayed CaP-coated oral implants subjected to occlusal load, an experimental study in the dog. Part I: short-term results", Clin. Oral. Impl. Res. vol. 21, pp. 1251-1263, 2010.

[37] R. Junker, P.J.D. Manders, J. Wolke, Y. Borisov, I. Braceras, J.A. Jansen, "Loaded microplasma-sprayed CaP-coated implants in vivo", J. Dent. Res., vol. 82, pp. 1489-1493, 2010.

[38] A. Dey, K. Mukhopadhyay, S. Gangadharan, M.K. Sinha, D. Basu, "Characterization of microplasma sprayed hydroxyapatite coating", J. Thermal Spray Technol., vol. 18 no. 4, pp. 578-592, 2009.

[39] A. Dey, K. Mukhopadhyay, S. Gangadharan, M.K. Sinha, D. Basu, "Development of hydroxyapatite coating by microplasma spraying", Mater. Manuf. Proc., vol. 24, pp. 1321-1330, 2009.

[40] A. Dey, K. Mukhopadhyay, "In vitro dissolution, microstructural and mechanical characterizations of microplasma-sprayed hydroxyapatite coating", Int. J. Appl. Ceram. Technol., vol. 11 no. 1, pp. 65-92, 2014

[41] A. Dey, "Physico-chemical and mechanical characterization of bioactive ceramic coating", $\mathrm{PhD}$ thesis, Bengal Engineering and Science University, Shibpur, India, 2010.

[42] D. Garcia-Alonso, M. Parco, J. Stokes, L. Looney, "Low-energy plasma spray (LEPS) deposition of hydroxyapatite/poly-ecaprolactone biocomposite coatings", J. Thermal Spray Technol., vol. 21 no. 1, pp. 132-143, 2012.

[43] Demnati, M. Parco, D. Grossin, I. Fagoaga, C. Drouet, G. Barykin, C. Combes, I. Braceras, S. Goncalves, C. Rey, "Hydroxyapatite coating on titanium by a low energy plasma spraying mini-gun", Surf. Coat. Technol., vol. 206, pp. 2346-2353, 2012.

[44] K. Tonsuaadu, K.A. Gross, L. Pluduma, M. Veiderma, "A review on the thermal stability of calcium apatites", J. Therm. Anal. Calorim., vol. 110, pp. 647-659, 2012.

[45] J.H. Shepherd, D.V. Shepherd, S.M. Best, "Substituted hydroxyapatites for bone repair", J. Mater. Sci. Mater. Med., vol. 23, pp. 2335-2347, 2012.

[46] Lindahl, W. Xia, J. Lausmaa, H. Engqvist, "Incorporation of active ions into calcium phosphate coatings, their release behavior and mechanism", Biomed. Mater., vol. 7, article ID: 045018, 2012.

[47] S. Overgaard, M. Lind, K. Josephsen, A.B. Maunsbach, C. Bünger, K. Soballe, "Resorption of hydroxyapatite and fluorapatite ceramic coatings on weight-bearing implants: A quantitative and morphological study in dogs", J. Biomed. Mater. Res. vol. 39, pp. 141-152, 1998

[48] Demnati, D. Grossin, C. Combes, M. Parco, I. Braceras, C. Rey, “A comparative physico-chemical study of chlorapatite and hydroxyapatite: from powders to plasma sprayed thin coatings", Biomed. Mater., vol. 7, pp. 054101, 2012.

[49] A.H. Hoekstra, "The chemistry and luminescence of antimonycontaining calcium chlorapatite", Ph.D. Thesis, Eindoven University, Eindoven, (1967).

[50] E. Garcia-Tunon, R. Couceira, J. Franco, E. Saiz, F. Guitian, "Synthesis and characterization of large chlorapatite single-crystals with controlled morphology and surface roughness", J. Mater. Sci. Mater. Med., vol. 23, pp. 2471-2482, 2012.

[51] J.S. Prener, "Nonstoichiometry in calcium chlorapatite", J. Solid. State Chem., vol. 3, pp. 49-55, 1971

[52] Demnati, "Developpement et characterisation de revêtements bioactifs d'apatite obtenus par projection plasma à basse énergie : 
application aux implants biomédicaux", Ph.D. Thesis, Institut National Polytechnique de Toulouse, Toulouse, France.

[53] P.E. Mackie, J.C. Elliott, R.A. Young, "Monoclinic structure of synthetic Ca5(PO4)3Cl, chlorapatite", Acta Cryst., vol. B28, pp. 1840-1848, 1972.

[54] G. Montel, G. Bonel, J.C. Trombe, J.C. Heughebaert, C. Rey, "Progrès dans le domaine de la chimie des composés phosphorés solides à structure d'apatite. Application à la biologie et au traitement des minerais", Pure Appl. Chem., vol. 52, pp. 973987, 1980

[55] G.C. Maiti, F. Freund, "Incorporation of chlorine into hydroxyapatite", J. Inorg. Nucl. Chem., vol. 43, pp. 2633-2637, 1981.

[56] J.C. Elliott, "Structure and chemistry of the apatites and other calcium orthophosphates", Amsterdam, Elsevier, 1994.

[57] T.S.B Narasaraju, K.K. Rao, U.S. Rai, "Determination of solubility products of hydroxyapatite, chlorapatite, and their solid solutions", Can. J. Chem. vol. 57, pp. 1919-1922, 1979.

[58] V.M. Valyashko, L.N. Kogarko, Khodakovskiy, "Stability of fluorapatite, chlorapatite, and hydroxyapatite in aqueous solutions at different temperatures" Geochemistry Int. USSR, vol. 5, pp.2130, 1968.

[59] E. Dykes, J.C. Elliott, "The occurrence of chloride ions in the apatite lattice of Holly Springs hydroxyapatite and dental enamel", Calcif. Tissue Res., vol. 7, pp. 241-248, 1971.

[60] G. Barykin, "Thermal spraying method and device", WO Patent $\mathrm{WO} / 2008 / 000,851,2008$.

[61] J.C. Trombe, G. Montel, "Some features of the incorporation of oxygen in different oxidation states in the apatite lattice“, J. Inorg. Nucl. Chem., vol. 40, pp. 15-21, 1978.

[62] C. Rey, O. Marsan, C. Combes, C. Drouet, D. Grossin, S. Sarda, "Characterization of calcium phosphates using vibrational spectroscopies" Chapter 8 in Advances in Calcium Phosphate Biomaterials, Springer Series in Biomaterials Sciece and Engineering, B. Ben Nissan, Ed. Berlin Heidelberg, Springer Verlag, 2014, pp. 229-266.

[63] I. Demnati, D. Grossin, C. Combes, C. Rey, "Plasma sprayed apatite coatings: review of physical- chemical aspects and their biological consequences“, J. Med. Biol. Eng., vol. 34, pp. 1-7, 2014.

[64] J. C. Trombe, "Contribution à l'étude de la décomposition et de la réactivité de certaines apatites hydroxylées, carbonatées ou fluorées alcalino-terreuses," PhD. Thesis at University Paul Sabatier of Toulouse, 1972.
[65] C.C. Berndt, M. Fahad Hasan, U. Tietz, K.-P. Schmitz, "A review of hydroxyapatite coatings manufactured by thermal spray" Chapter 9 in Advances in Calcium Phosphate Biomaterials, Springer Series in Biomaterials Sciece and Engineering, B. Ben Nissan, Ed. Berlin Heidelberg, Springer Verlag, 2014, pp. 267-329.

[66] H. Li, K.A. Khor, P. Cheang, "Thermal sprayed hydroxyapatite splats: nanostructures, pore formation mechanism and TEM characterization", Biomaterials, vol. 25, pp. 3463-347, 2004.

[67] A.A. Roche, A.K. Behme Jr., J.S. Solomon "A three-point flexure test configuration for improved sensitivity to metal/ adhesive interfacial phenomena", Int. J. Adhesion Adhesives, vol. 2, pp. 249254, 1982.

[68] A.A. Roche M. Aufray J. Bouchet, "The Role of the Residual Stresses of the Epoxy-Aluminum Interphase on the Interfacial Fracture Toughness", Adhesion, vol. 82, pp. 861-880, 2006.

[69] M. Coulaud, "Role des interfaces et interphases dans les assemblages collés", PhD thesis, INSA, Lyon, 2007.

[70] M. Aufray, A.A. Roche, "Residual stresses and practical adhesion: effect of organo-metallic complex formation and crystallization", J. Adhesion Sci. Technol., vol. 20, pp. 1889-1903, 2006.

[71] J.C. Elliott, R.A. Young, "Conversion of single crystals of chlorapatite into single crystals of hydroxyapatite", Nature, vol. 214, pp. 904-906, 1967

[72] Garcia-Tunon, J. Franco, S. Eslava, V. Bhakhri, E. Saiz, F. Giuliani, F. Guitan, "Synthesis and optimization of the production of millimeter-sized hydroxyapatite single crystals by $\mathrm{Cl}^{-} \mathrm{OH}^{-}$ion exchange", J. Am. Ceram. Soc., vol. 96, pp. 759-765, 2013.

[73] S. Dyshlovenko, L. Pawlowski, B. Pateyron, I. Smurov, J.H Harding, "Modelling of plasma particle interactions and coating growth for plasma spraying of hydroxyapatite", Surf. Coat. Technol., vol. 200, pp. 3757-3769, 2006.

[74] P. Schmittinger, T. Florkiewicz, L.C. Curlin, B. Lüke, R. Scannell, T. Navin, E. Zelfel, R. Bartsch. "Chlorine" in Ullmann's Encyclopedia of Industrial Chemistry, Wiley-VCH Verlag GmbH \& Co, 2006 Wiley . doi:10.1002/14356007.a06_399.pub2

[75] R. Kumar, P. Cheang, K.A. Khor, "Phase composition and heat of crystallisation of amorphous calcium phosphate in ultra-fine radio frequency suspension plasma sprayed hydroxyapatite powders", Acta Mater, vol. 52, pp. 1171-1181, 2004.

[76] Y.C. Tsui, C. Doyle, T.W. Clyne, "Plasma sprayed hdroxyapatite coatings on titanium substrates. Part 2: optimization of coating properties", Biomaterials, vol. 19, pp. 2031-2043, 1998. 